\title{
Notes on the Venezuelan jumping spiders described by Caporiacco (Araneae, Salticidae)
}

\author{
Gustavo R. S. Ruiz ${ }^{1,2} \&$ Antonio D. Brescovit ${ }^{1}$ \\ ${ }^{1}$ Laboratório de Artrópodes, Instituto Butantan. Avenida Vital Brazil 1500, 05503-900 São Paulo, São Paulo, Brasil. \\ E-mail: adbresc@terra.com.br \\ 2 Departamento de Zoologia, Instituto de Biociências, Universidade de São Paulo. Caixa Postal 11461, 05422-970 São \\ Paulo, São Paulo, Brasil. E-mail: gustavoruiz86@hotmail.com
}

\begin{abstract}
The type specimens of 15 nominal salticid species from Venezuela described by Lodovico di Caporiacco were examined. In this paper we present brief redescriptions when deemed necessary as well as three new synonymies: Aculeobreda Caporiacco, 1955 = Pachomius Peckham \& Peckham, 1896; Sidusa variegata Caporiacco, 1955 = Simonurius quadratarius (Simon, 1901); Sitticus cabellensis Prószynski, 1971 = Pseudattulus incertus Caporiacco, 1955; and five new transferences: Aculeobreda hadzji Caporiacco, 1955 = Pachomius hadzji (Caporiacco, 1955) comb. nov.; Dendryphantes franganilloi Caporiacco, 1955 = Metacyrba franganilloi (Caporiacco, 1955) comb. nov.; Evarcha venezuelica Caporiacco, 1955 = Asaracus venezuelicus (Caporiacco, 1955) comb. nov.; Pseudamphidraus femellus Caporiacco, 1955 = Marma femella (Caporiacco, 1955) comb. nov.; Scopocira sexspinosa Caporiacco, 1955 = Sassacus sexspinosus (Caporiacco, 1955) comb. nov. Phintodes craneae Caporiacco, 1955, described based on a juvenile, must be treated as species inquirenda.

KEY WORDS. Neotropical, systematics, taxonomy, Venezuela.
\end{abstract}

RESUMO. Notas sobre as aranhas papa-mosca venezuelanas descritas por Caporiacco (Araneae, Salticidae). Os exemplares-tipo de 15 espécies nominais de Salticidae da Venezuela descritas por Lodovico di Caporiacco são examinados. Neste trabalho são apresentadas breves redescrições quando necessário, e três novas sinonímias: Aculeobreda Caporiacco, 1955 = Pachomius Peckham \& Peckham, 1896; Sidusa variegata Caporiacco, 1955 = Simonurius quadratarius (Simon, 1901); Sitticus cabellensis Prószynski, 1971 = Pseudattulus incertus Caporiacco, 1955; e cinco novas transferências: Aculeobreda hadzji Caporiacco, 1955 = Pachomius hadzji (Caporiacco, 1955) comb. nov.; Dendryphantes franganilloi Caporiacco, 1955 = Metacyrba franganilloi (Caporiacco, 1955) comb. nov.; Evarcha venezuelica Caporiacco, 1955 = Asaracus venezuelicus (Caporiacco, 1955) comb. nov.; Pseudamphidraus femellus Caporiacco, $1955=$ Marma femella (Caporiacco, 1955) comb. nov.; Scopocira sexspinosa Caporiacco, 1955 = Sassacus sexspinosus $($ Caporiacco, 1955) comb. nov. Phintodes craneae Caporiacco, 1955, descrita a partir de um jovem, é tratada como species inquirenda. PALAVRAS CHAVE. Neotropical, sistemática, taxonomia, Venezuela.

The paper concerning the Venezuelan spider species described by Lodovico di Caporiacco (CAPORIACCO 1955) was prepared during the few last months of his life, and finished at the hospital while he was very ill (RACENIS 1955). The complete manuscript was received post mortem and included several errors that could not be corrected (RACENIS 1955). In that article, Caporiacco described three new genera and 18 new species of the family Salticidae. The drawings presented by the author, however, were very poor, and these species remained unrecognizable until now. The measurements taken by him are also very different from those taken by us for the present redescriptions. Through courtesy of Rubén Candia, from the Museo de Biología, Facultad de Ciencias, Universidad Central de Venezuela, Caracas, Venezuela (MUCV), we have recently had the opportunity to ex- amine 15 type specimens from the total of 17 that should be deposited in that collection. The type of Haplopsecas annulipes Caporiacco, that should be deposited in the Università di Parma, Parma, Italy, was not examined. In this paper we present the results of the examination of this material, including brief redescriptions and nomenclatural changes, improving the knowledge on the taxonomy of South American jumping spiders.

\section{MATERIAL AND METHODS}

The material examined was in very bad condition and poor conservation state, possibly dried out several times through the years. Color patterns and ornamentation, such as hairs, disappeared in most specimens, all presenting uniform faded brown coloration. 
The measurements are given in millimeters. The abbreviations used throughout the text are: RTA: retrolateral tibial apophysis; ALE: anterior lateral eyes; PME: posterior median eyes; PLE: posterior lateral eyes; d: dorsal; p: prolateral; $\mathrm{r}$ : retrolateral; v: ventral; di: distal.

\section{Asaracus venezuelicus (Caporiacco, 1955) comb. nov.} Figs $1-2$

Evarcha venezuelica Caporiacco, 1955: 429, fig. 70, female holotype from Rancho Grande, Aragua, Venezuela, 13.VII. 1949, J. Racenis leg., MUCV 881 (examined); Brignoli, 1983: 638; Platnick, 2004.

Condition: right leg I missing, body totally dehydrated.

Comments. Females of the genus Asaracus C.L. Koch are still poorly known. Tentatively, we propose this new combination due to the fact that this species presents very stout chelicerae, a wide carapace and very long copulation ducts (Fig. 2), such as those observed in 'true' Asaracus undescribed females.

Redescription. Total length: 6.50. Carapace 3.20 long, 2.70 wide and 1.75 high. Body uniformly faded brown. Chelicerae stout, with two teeth on promargin, one on retromargin. Leg formula: I IV III II, legs I and II stout. Spinulation: femur I, II, III d1-1-1, p2di, IV d1-1-1, r1di, patella I, II 0, III, IV r1, tibia I v2-2-2, II v1r-2-2, p1di, III v1p-2di, p1-1-1, r1-1-1, IV v1p1rdi, p1-1, r1-1-1, metatarsus I, II v2-2, III, IV v2-2, p1-2di, r12. Epigynum with a small atrium, internally with long and sinuous copulation ducts, small spermathecae and distal fertilization ducts (Figs 1-2).

\section{Dendryphantes barrosmachadoi Caporiacco, 1955}

Dendryphantes barrosmachadoi Caporiacco, 1955: 442, fig. 80, female holotype from Rancho Grande, Aragua, Venezuela, III.1949, Marcuzzi leg., MUCV 700 (lost, not examined); Brignoli,1983: 636; Platnick, 2004.

Comments. Epigynum illustrations presented by the author (CAPORIACCO 1955: 442, fig. 80) seems to be typical of dendryphantine. Nevertheless, further information can only be given after improving the knowledge on the Venezuelan fauna, inasmuch as the type specimen, that should be deposited in the MUCV, is lost.

\section{Ilargus singularis Caporiacco, 1955}

Ilargus singularis Caporiacco, 1955: 433, figs 74a-d, male holotype from El Junquito, Distrito Federal, Venezuela, 1948, Marcuzzi leg., MUCV 692 (examined); Brignoli, 1983: 641; Platnick, 2004.

Condition: very badly preserved; legs, palps, abdomen and right chelicera missing.

Comments. This species seems to be a 'true' Ilargus. Although the palps are both absent in the type specimen, Caporiacco's detailed illustration of the RTA (CAPORIACCO 1955:
434, fig. 74c) allows the identification of this species for future studies on the Venezuelan spiders.

Redescription: Carapace 1.17 long, 0.87 wide, 0.62 high. Chelicerae small, vertical, with two teeth on promargin, one bicuspid on retromargin.

\section{Marma femella (Caporiacco, 1955) comb. nov.}

\section{Figs 3-4}

Pseudamphidraus femellus Caporiacco, 1955: 422, fig. 67, female holotype from La Pecha, Islas Los Frailes, Distrito Federal, Venezuela, XII.1948, Marcuzzi leg., MUCV 710 (examined); Brignoli, 1983: 652; Platnick, 2004.

Condition: well preserved, slightly dehydrated.

Diagnosis. This species is closely related to both Marma baeri Simon, 1902 and Marma nigritarsis (Simon, 1900). It can be distinguished from $M$. nigritarsis by the shorter copulation ducts, and from M. baeri by the copulation openings closer together (Figs 3-4).

Redescription. Total length: 2.90. Carapace 1.60 long, 1.20 wide, 0.75 high. Body uniformly faded brown, apparently with dark rings on legs, abdomen covered by long hairs. Chelicerae with two teeth on promargin, four on retromargin, fused at the base. Leg formula: IV III I II.

\section{Metacyrba franganilloi (Caporiacco, 1955) comb. nov.}

\section{Figs 5-6}

Dendryphantes franganilloi Caporiacco, 1955: 441, fig. 79, female holotype from Pueblo Nuevo, Falcón, Venezuela, X.1948, Marcuzzi leg., MUCV 739 (examined); Brignoli, 1983: 636; Platnick, 2004.

Condition: Left legs I and II missing, right legs I and II detached, chelicerae destroyed.

Redescription. Total length: 4.25. Carapace dark brown, 1.90 long, 1.40 wide, 0.70 high. Leg formula: IV I II III, leg I very stout. Epigynum with an upside down drop shaped opening (Fig. 5). Internally with wide copulation ducts, small spermathecae and distal fertilization ducts (Fig. 6).

\section{Pachomius Peckham \& Peckham, 1896}

Pachomius Peckham \& Peckham, 1896: 80.

Aculeobreda Caporiacco, 1955: 443. Syn. nov. (by transfer of type species).

\section{Pachomius hadzji (Caporiacco, 1955) comb. nov.}

\section{Figs 7-8}

Aculeobreda hadzji Caporiacco, 1955: 444, figs 81a-b, male holotype from Caracas, Distrito Federal, Venezuela, 4.V.1949, Marcuzzi leg., MUCV 736 (examined); Brignoli, 1983: 631; Platnick, 2004.

Condition: right leg I and right palp missing. 

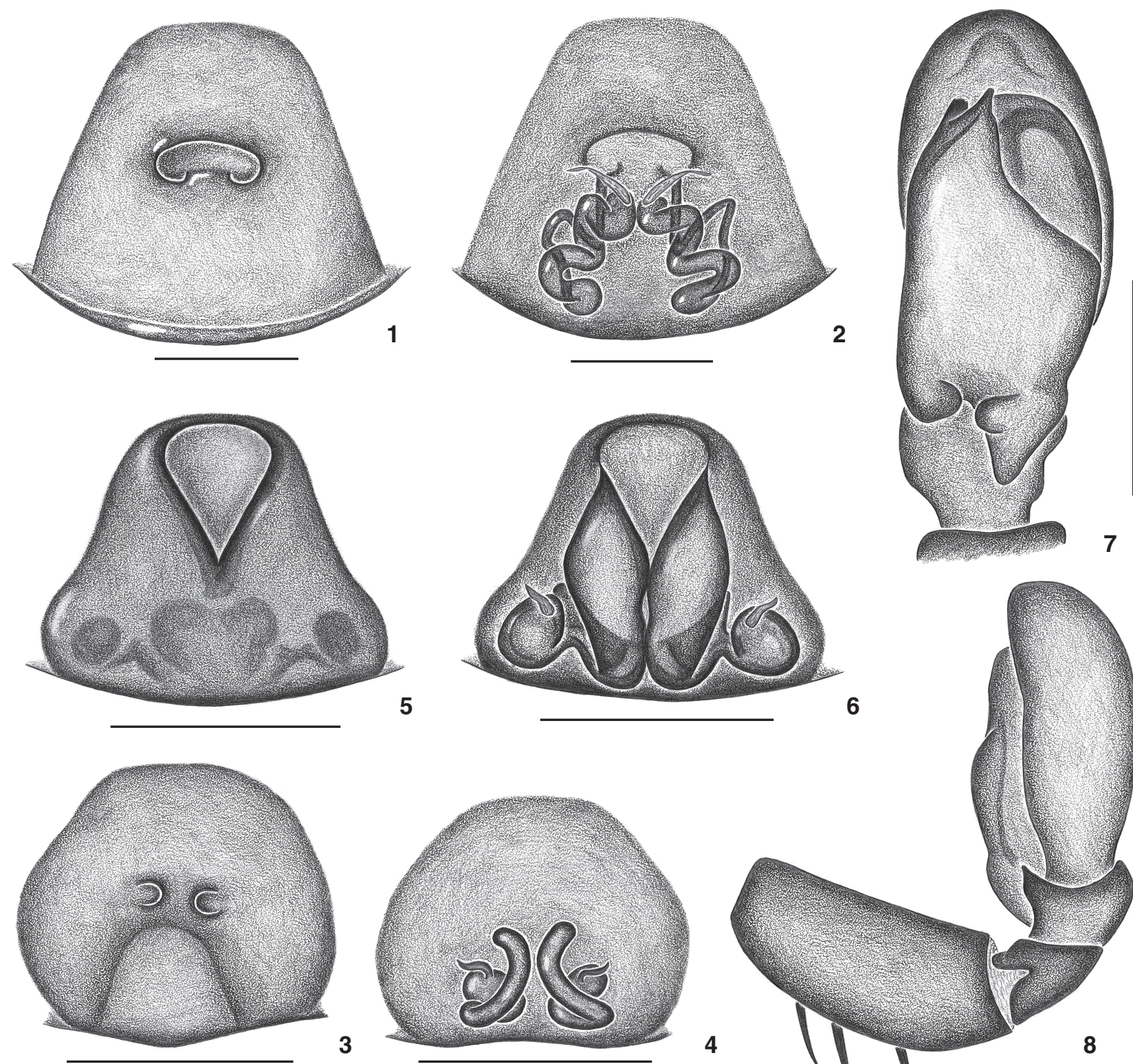

4

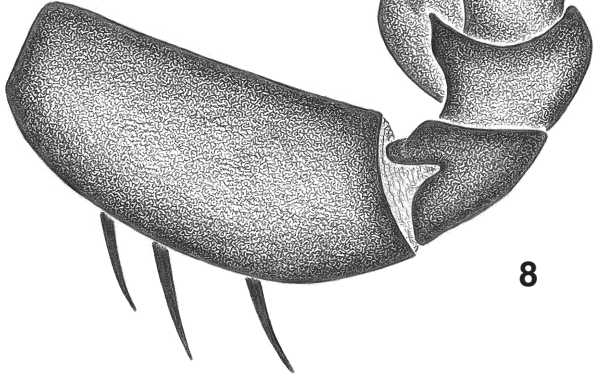

Figures 1-8. (1-2) Asaracus venezuelicus comb. nov.: (1) epigynum, ventral view; (2) dorsal view; (3-4) Marma femella comb. nov.: (3) epigynum, ventral view; (4) dorsal view; (5-6) Metacyrba franganilloi comb. nov.: (5) epigynum, ventral view; (6) dorsal view; (7-8) Pachomius hadzji comb. nov.: (7) male palp, ventral view; (8) retrolateral view. Scale lines: $0.25 \mathrm{~mm}$.

Comments. This species seems to be very close related to both Pachomius villeta Galiano, 1994 and Phiale bilobata (F.O.P.Cambridge, 1901).

Redescription. Total length: 4.00. Carapace dark brown, 2.05 long, 1.35 wide, 0.77 high, with white hairs laterally and around eyes, except among PME and PLE. Cephalic region darker. Clypeus with long white hairs. Chelicerae dark brown, with two teeth on promargin, one on retromargin. Endites with retrolateral projection like that of $P$. villeta (GALIANO 1994: 216, fig. 11). Palp with a basal tegular projection (Figs 7-8). Leg formula: IV I III II. Abdomen faded light brown. Spinnerets light brown. 


\section{Pensacola poecilocilia Caporiacco, 1955}

Figs 9-10

Pensacola poecilocilia Caporiacco, 1955: 436, fig. 76, female holotype from Paraguaipoa, Zulia, Venezuela, VII.1949, Marcuzzi leg., MUCV 724 (examined); Brignoli, 1983: 650; Platnick, 2004.

Condition: well preserved, slightly dehydrated.

Comments. This species is not a 'true' Pensacola. The reduced epigynum and carapace shape suggest that it is in fact in Dendryphantinae.

Redescription. Total length: 4.40. Carapace 1.90 long, 1.70 wide, 1.00 high. Body faded brown but abdomen grayish. Chelicerae with two teeth on promargin, one on retromargin. Leg formula: I IV II III. Epigynum with a very small atrium and hardly sulcated posteriorly, internally with long copulation ducts, coiled spermathecae and distal fertilization ducts (Figs 9-10).

\section{Pensacola tuberculotibiata Caporiacco, 1955} Figs 11-12

Pensacola tuberculotibiata Caporiacco, 1955: 435, figs 75a-b, male holotype from Rancho Grande, Aragua, Venezuela, 9.VIII. 1949, J. Racenis leg., MUCV 715 (examined); Brignoli, 1983: 650; Platnick, 2004.

Condition: Very dehydrated, chelicerae and right palp missing, left leg IV detached.

Comments. This species is probably in Euophryinae, but has a unique proximal rounded projection on the palpal tibia (Figs 11-12), that is probably used during copulation. It is possible that this male goes with the female described as Platypsecas razzabonii Caporiacco, that presents a proportional proximal hood on the epigynum (Fig. 15), but both type specimens are too damaged to corroborate this hypothesis and thus for now we avoid the synonymy.

Redescription. Total length: 4.05. Carapace 2.20 long, 1.75 wide, 1.25 high. Body uniformly faded brown. Palp with a rounded proximal projection on tibia (Fig. 12) and distally coiled embolus (Fig. 11). Leg formula: I IV III II.

\section{Phidippus exlineae Caporiacco, 1955}

\section{Figs 13-14}

Phidippus exlineae Caporiacco, 1955: 439, fig. 78, female holotype from Mucuchíes, Mérida, Venezuela, I.1950, Marcuzzi leg., MUCV 699 (examined); Brignoli, 1983: 650; Edwards, 2004: 5; Platnick, 2004.

Condition: left palp, right legs I and II detached, abdomen crushed.

Comments. This species is not a 'true' Phidippus (sensu EDWARDS 2004: 5). Because of the lack of studies on neotropical Dendryphantinae, we avoid any taxonomic changes for now.

Redescription. Total length: 8.50. Carapace $3.90 \mathrm{long}$, 3.20 wide, 1.70 high. Body uniformly faded brown. Chelicerae with two teeth on promargin, one on retromargin. Leg for- mula: I IV III II, leg I very stout. Epigynum with oval and medium atrium and posterior border sulcated (Fig. 13). Internally with long, larger and sinuous copulation ducts, very small spermathecae and distal fertilization ducts (Fig. 14).

\section{Platypsecas razzabonii Caporiacco, 1955} Figs 15-16

Platypsecas razzabonii Caporiacco, 1955: 419, fig. 65, female holotype from El Junquito, Distrito Federal, Venezuela, VIII.1948, Marcuzzi leg., MUCV 713 (examined); Brignoli, 1983: 651; Platnick, 2004.

Condition: left leg III missing, right leg III and legs IV broken.

Comments. This must be a valid genus, possibly in Euophryinae (see comments under Pensacola tuberculotibiata).

Redescription. Total length: 6.20. Carapace 2.70 long, 2.00 wide, 0.70 high. Body uniformly faded brown, with a longitudinal dorsal stripe of white hairs on the anterior two thirds of the abdomen. Chelicerae with three teeth on promargin, two on retromargin. Leg formula: IV I II?, leg I very stout. Epigynum with a hood proximally, small, rounded spermathecae and distal fertilization ducts (Figs 15-16).

\section{Pseudattulus beieri Caporiacco, 1955}

Pseudattulus beieri Caporiacco, 1955: 447, fig. 83, female holotype from Laguna Honda, Isla de Margarita, Nueva Esparta, Venezuela, III.1948, Marcuzzi leg., MUCV 1194 (lost, not examined); Brignoli, 1983: 652; Platnick, 2004.

Comments. The illustration of the epigynum presented by Caporiacco (1955: 447, fig. 83), probably published upside down, enables the identification of this species for future studies on the Venezuelan spiders.

\section{Pseudattulus incertus Caporiacco, 1955}

Pseudattulus incertus Caporiacco, 1955: 446, fig. 82, female holotype from Maiquetía, Distrito Federal, Venezuela, IX. 1948, Marcuzzi leg., MUCV 929 (examined); Brignoli, 1983: 652; Platnick, 2004.

Sitticus cabellensis Prószynski, 1971: 198, figs 31-39, female holotype and male allotype from Puerto Cabello, Carabobo, Venezuela, E. Simon leg., Muséum National d'Histoire Naturelle (not examined); Brignoli, 1983: 655; Platnick, 2004. Syn. nov.

Condition: right leg III, left legs II, III and IV and chelicerae missing, abdomen detached.

Comments. The genus Pseudattulus Caporiacco has not yet been revised, but this species is very different from the type species Pseudattulus kratochvili Caporiacco, 1947, and probably belongs to a new genus. The epigynum of the type specimen is identical to that of Sitticus cabellensis described by PrószynsKI (1971: 200, figs 32-33).

Description. Male and female described by Prószynski (1971: 198, figs 31-39). 

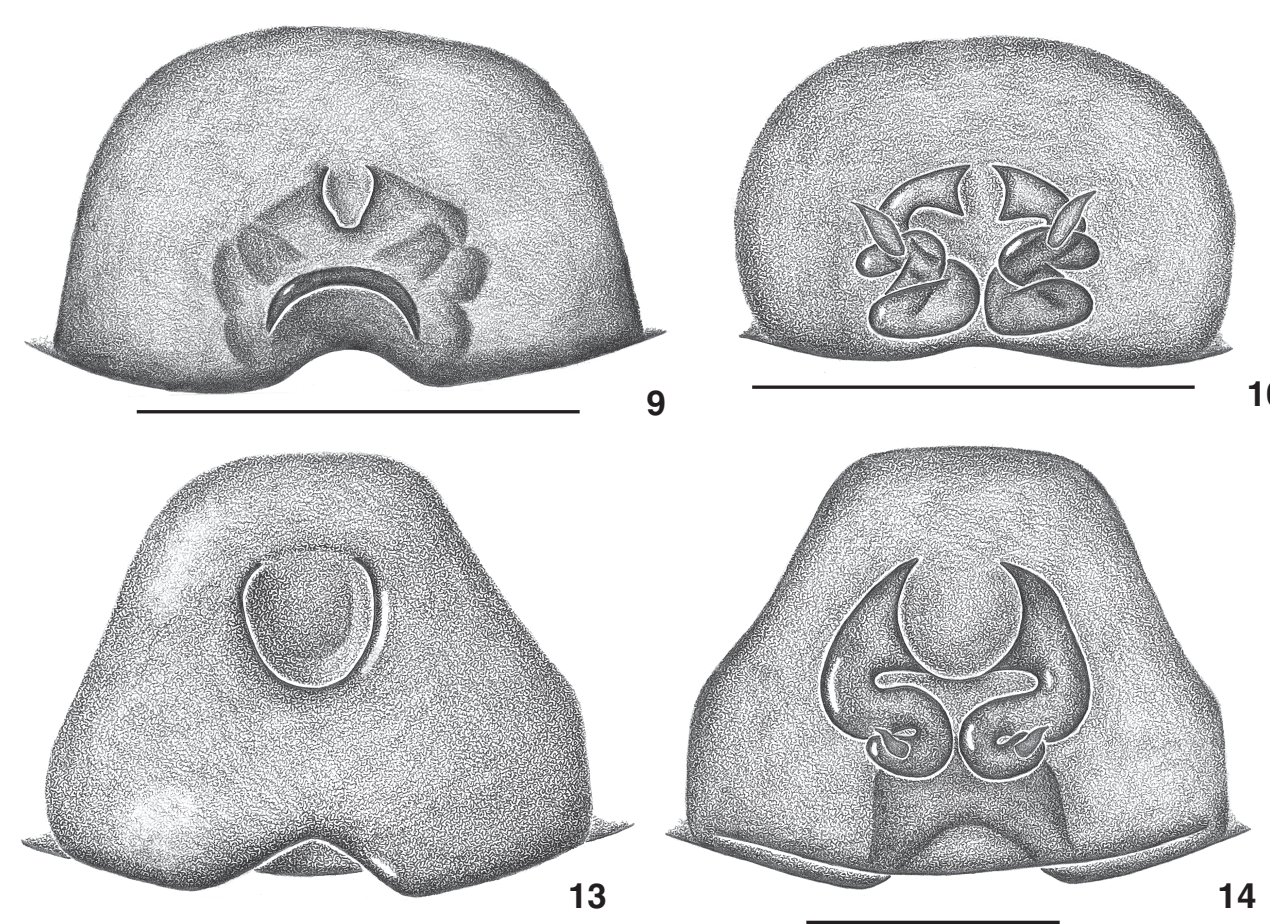

10
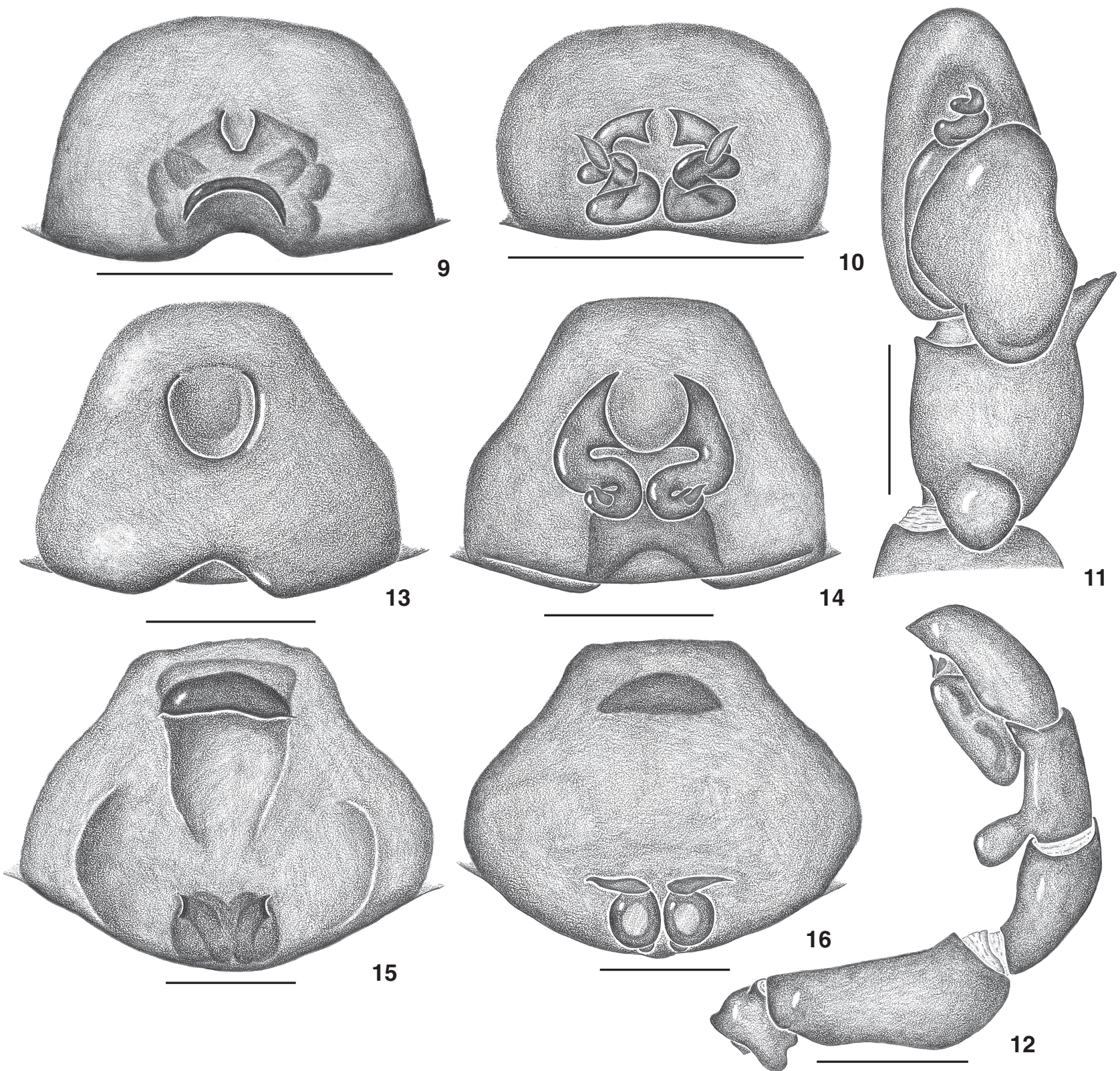

Figures 9-16. (9-10) Pensacola poecilocilia: (9) epigynum, ventral view; (10) dorsal view; (11-12) Pensacola tuberculotibiata: (11) male palp, ventral view; (12) retrolateral view; (13-14) Phidippus exlineae: (13) epigynum, ventral view; (14) dorsal view; (15-16) Platypsecas razzabonii: (15) epigynum, ventral view; (16) dorsal view. Scale lines: (9-10) $0.125 \mathrm{~mm}$; (11-16) $0.25 \mathrm{~mm}$.

\section{Sassacus sexspinosus (Caporiacco, 1955) comb. nov. Figs 17-19}

Scopocira sexspinosa Caporiacco, 1955: 426, figs 69a-c, male holotype from Rancho Grande, Aragua, Venezuela, II.1949, Marcuzzi leg., MUCV 843 (examined); Brignoli, 1983: 654; Platnick, 2004.
Condition: right palp and right leg I missing, abdomen detached.

Comments. This species is very closely related to the South American species included by Simon in the genus Sassacus Peckham \& Peckham, but not similar to the type species $S$. papenhoei Peckham \& Peckham, 1888, described from the United States of America. It is possible that the South Ameri- 


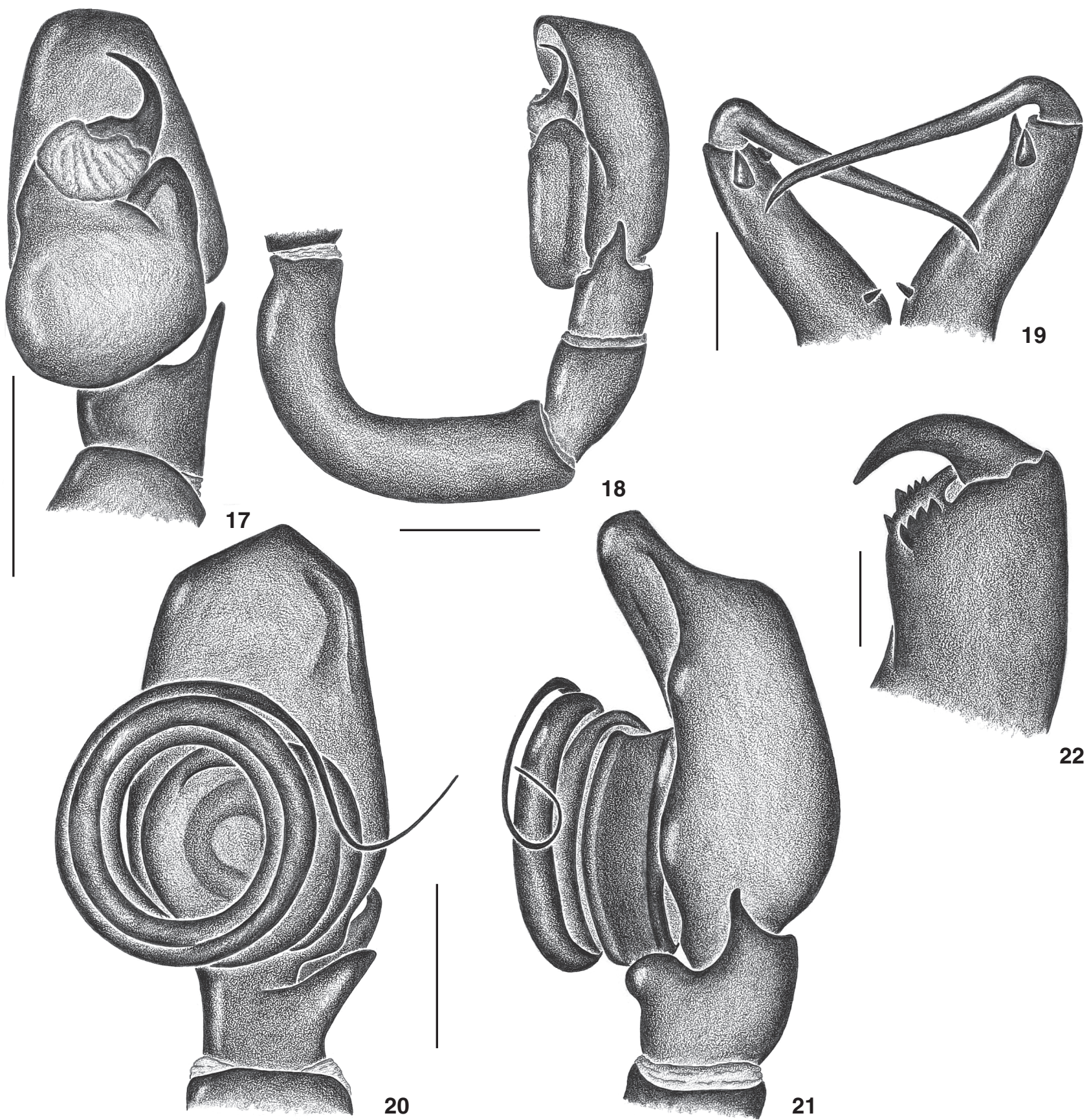

Figures 17-22. (17-19) Sassacus sexspinosus comb. nov.: (17) male palp, ventral view; (18) retrolateral view; (19) male chelicerae, ventral view; (20-22) Titanattus novarai: (20) male palp, ventral view; (21) retrolateral view; (22) male chelicera, ventral view. Scale lines: (17-18) $0.25 \mathrm{~mm}$; (19) $0.50 \mathrm{~mm}$; (20-22) $0.25 \mathrm{~mm}$.

can species belong to a new genus in the subfamily Dendryphantinae. Although there are already three species of Sassacus described from Venezuela (S. resplendens Simon, 1901, S. flavicinctus Crane, 1949 and S. ocellatus Crane, 1949), the group is still poorly understood and the species might be morphologically very close, which is common in many Dendryphantinae genera.

Redescription. Total length: 3.50. Carapace with narrow stripes of white hairs on borders, 1.55 long, 1.55 wide, 1.00 high,

Revista Brasileira de Zoologia 22 (3): 753-760, setembro 2005 
with a pair of stripes of white hairs extending from the ALE to the middle of the thoracic region, where they fuse at the middle. Clypeus densely covered by white hairs. Abdomen apparently with two transverse stripes of white hairs on the posterior half. Chelicerae well developed (Fig. 19). Palp as in figures 17-18, with very curved femur. Leg formula: I IV II III.

\section{Simonurius quadratarius (Simon, 1901)}

Akela quadrataria Simon, 1901: 145, male holotype from Colonia Tovar, Aragua, Venezuela, E. Simon leg., Muséum National d'Histoire Naturelle (not examined); Galiano, 1963: 287, pl. IV, figs 3-5; Platnick, 2004.

Sidusa variegata Caporiacco, 1955: 430, figs 71a-c, male holotype from El Junquito, Distrito Federal, Venezuela, 16.X. 1949, Marcuzzi leg., MUCV 737 (examined); Brignoli, 1983: 654; Platnick, 2004. Syn. nov.

Simonurius quadratarius; Galiano, 1988: 300; Platnick, 2004.

Condition: right legs I and II and left palp missing, right leg IV and abdomen detached.

Comments. The palp of the type specimen of Sidusa variegata is exactly alike that of Simonurius quadratarius described by Galiano (1963: 287, pl. IV, figs 3-5).

Description. Male and female described by GaLIANo (1963).

\section{Stoidis squamulosa Caporiacco, 1955}

Stoidis squamulosa Caporiacco, 1955: 432, figs 73a-b, male holotype from Maiquetía, Distrito Federal, Venezuela, XII.1948, Marcuzzi leg., MUCV 696 (examined); Brignoli, 1983: 655; Platnick, 2004.

Condition: Chelicerae, palps, both legs I, left legs II and III and right leg IV missing, right leg II detached.

Comments. This species is certainly in Euophryinae. Although both palps are absent, Caporiacco's illustrations of the male palp (CAPORIACCO 1955: 433, figs 73a, b) allow the identification of this species for future studies on the Venezuelan spiders.

Redescription. Total length: 2.20. Carapace 1.42 long, 1.02 wide, 0.75 high.

\section{Titanattus novarai Caporiacco, 1955}

\section{Figs 20-22}

Titanattus novarai Caporiacco, 1955: 424, fig. 68, male holotype from El Junquito, Distrito Federal, Venezuela, 10.X. 1949, Marcuzzi leg., MUCV 821 (examined); Brignoli, 1983: 657; Platnick, 2004. broken.

Condition: right palp and left leg I missing, left leg II

Comments. This species seems to be a 'true' Titanattus. We did not try to place the embolus back in the resting position to avoid damaging it. We suppose that the curling tip of the embolus lies on the narrow channel at the ventral tip of the cymbium (Fig. 20).
Redescription. Total length: 5.00. Carapace 2.50 long, 2.00 wide, 1.95 high. Carapace reddish brown, abdomen and legs light brown. Chelicerae very long, with five teeth on promargin, four on retromargin, fused at the base (Fig. 22). Palp with bifid RTA and long, very coiled embolus (Figs 20-21). Leg formula: I III IV II.

\section{Tylogonus craneae (Caporiacco, 1955)}

Phintodes craneae Caporiacco, 1955: 438, fig. 77, holotype immature from Rancho Grande, Aragua, Venezuela, 9.VIII. 1949, J. Racenis leg., MUCV 782 (examined).

Tylogonus craneae: Galiano 1985: 153; Brignoli, 1983: 651; Platnick, 2004.

Condition: right legs I and IV and palps missing.

Comments. This species must be treated as species inquirenda, inasmuch the type specimen is an immature and the species is unrecognizable.

\section{ACKNOWLEDGMENTS}

We wish to thank Rubén Candia, José A. González and J.C. Navarro, who made this research possible. We also thank G.B. Edwards, Cristina A. Rheims and Arno A. Lise for suggestions on the manuscript. This study was financed by $\mathrm{CNPq}$ (Conselho Nacional de Desenvolvimento Científico e Tecnológico) and FAPESP (Fundação de Amparo à Pesquisa de São Paulo, 99/05446-8).

\section{REFERENCES}

Brignoli, P.M. 1983. A catalogue of the Araneae described between 1940 and 1981. Manchester, Manchester University Press, 755p.

Caporiacco, L. DI. 1955. Estudios sobre los arácnidos de Venezuela. 2a parte: Araneae. Acta Biologica Venezuelica, Caracas, 1: 265-448.

EDWARDS, G.B. 2004. Revision of the jumping spiders of the genus Phidippus (Araneae: Salticidae). Occasional Papers of the Florida State Collection of Arthropods, Gainesville, 11: 1156.

Galiano, M.E. 1963. Las especies americanas de arañas de la familia Salticidae descriptas por Eugène Simon: Redescripciones basadas en los ejemplares típicos. Physis (C), Buenos Aires, 23: 273-470.

Galiano, M.E. 1985. Tres nuevas especies de Tylogonus Simon, 1902 (Araneae, Salticidae). Historia Natural, Corrientes, 5: 153-160.

Galiano, M.E. 1988. Revisión de los géneros del grupo Hurieae (Araneae, Salticidae). Journal of Arachnology, Denver, 15: 285-301.

Galiano, M.E. 1994. Revision of the genus Pachomius (Araneae, Salticidae). Bulletin of the British Arachnology Society, Dorset, 9: 214-220. 
Pескнам, G.W. \& E.G. Peскнам. 1896. Spiders of the family Attidae from Central America and Mexico. Occasional Papers of the Natural History Society of Wisconsin, Wisconsin, 3: 1-101. Platnick, N.I. 2004. The world spider catalog, version 5.0. American Museum of Natural History, Available form World Wide Web at http://research.amnh.org/entomology/spiders/ catalog/index.html

Prószynski, J. 1971. Revision of the spider genus Sitticus Simon,
1901 (Aranei, Salticidae). II. Sitticus saxicola (C.L. Koch, 1848) and related forms. Annales Zoologici, Warsaw, 28: 183-204.

RaCenIs, J. 1955. Remarks to Prof. Caporiacco's work "Studies on Venezuelan spiders". Acta Biologica Venezuelica, Caracas, 1: 449-451.

SimON, E. 1901. Descriptions d'arachnides nouveaux de la famille des Attidae (suite). Annales de la Société Entomologique de Belgique, Bruxelles, 45: 141-161.

Received in 10.I.2005; accepted in 22.VIII.2005. 